Article

\title{
The Impact of Haze Pollution on Firm-Level TFP in China: Test of a Mediation Model of Labor Productivity
}

\author{
Bin Li®, Shuai Shi and Yating Zeng * \\ School of Economics and Management, Beijing University of Chemical Technology, Beijing 100029, China; \\ libin@mail.buct.edu.cn (B.L.); 2018200852@mail.buct.edu.cn (S.S.) \\ * Correspondence: zengyating@mail.buct.edu.cn
}

Received: 4 August 2020; Accepted: 9 October 2020; Published: 14 October 2020

check for updates

\begin{abstract}
The core issue for China's economy to shift from high-speed growth to high-quality development is to raise total factor productivity (TFP). Based on the data of A-share listed companies from 2013 to 2017 and the air quality monitoring data released by the China National Environmental Monitoring Centre, this paper conducts an empirical test on the relationship between haze pollution, labor productivity, and firm-level TFP by using the mediation effect test model. The results show the following: First, haze pollution will reduce a firm's TFP. Second, labor productivity plays a partial intermediary role between haze pollution and a firm's TFP. Haze pollution will not only have a direct negative impact on a firm-level TFP but also reduce a firm-level TFP by reducing labor productivity. Subsequently, the robustness test was carried out by means of a substitution of independent variables and dependent variables, and the results all supported the hypotheses in this paper. In addition, the heterogeneity of the industry and the ownership of listed companies was analyzed, and the two-stage least squares (2SLS) method was used to solve the endogeneity problem. The conclusions of this paper are helpful to clarify the relationship between haze pollution, firm factor productivity, and firm-level TFP. The paper's findings also provide a practical basis for firms to further improve TFP from the perspective of air pollution problems such as haze.
\end{abstract}

Keywords: haze pollution; TFP; labor productivity; LP method

\section{Introduction}

From 1978 to 2015, China's economy grew at an average annual speed of 9.69\% (the data are from the 2016 China Statistical Yearbook and are calculated at constant prices based on 1978), creating a "miracle of growth" that has attracted worldwide attention. Firms have also taken advantage of the relatively low cost of labor, land, and other input factors, the increase of the use of which has enabled the firms to improve productivity and to achieve scale expansion. Therefore, both state-owned firms and foreign and private firms have also realized rapid expansion. As China's labor and other factor prices continue to rise and the international economic recovery continues to be weak, the downward pressure on China's domestic economy has increased (China's economy has entered a "new normal," with economic growth slowing to below 7\% (the data are from the 2017-2019 China Statistical Yearbook) in recent years), the pains of industrial restructuring have emerged, and the production and operation difficulties of firms have increased. Therefore, the report of the 19th National Congress of the Communist Party of China emphasized that the country should deepen the reform of the market economic system, transform the mode of economic development, and improve the quality of economic development [1]. As a microsubject in the macroeconomy, high-quality economic development needs to be realized by the high-quality development of firms in the final analysis. If firms want to achieve 
high-quality development, one of the important ways to accomplish this goal is by constantly improving their total factor productivity (TFP) in order to achieve quality change, efficiency change, and power change. At present, a large number of scholars have analyzed the influence of internal conditions, such as mergers, acquisitions, innovation, and research ability, and external market economy factors, such as financial development, the market system, and industrial policy, on a firm-level TFP [2-5]. However, so far, few scholars have started from the perspective of the external natural environment to analyze the impact of changes in the natural environment (such as air pollution, etc.) on a firm-level TFP [6-8].

China's extensive economic growth over the years has made people's living environment increasingly worse, as frequent haze weather and frequent extraordinary haze incidents have increased [9-14]. According to the Bulletin on the State of the Ecological Environment in China in 2017, 239 out of 338 cities exceeded environmental air quality standards, accounting for more than 70 percent [15]. Haze is a phenomenon in which a large number of extremely fine particles that are invisible to the naked eyes suspend in the air, causing the atmosphere to appear milky white and reduce visibility (this definition comes from the China National Environmental Monitoring Centre). A bad air environment not only affects people's physical and mental health but also reduces the quality of economic development [16]. To improve the environment and improve the quality of economic development, it is necessary to thoroughly control environmental pollution such as haze. The significance of controlling environmental pollution lies not only in the reduction of haze itself but also in the fundamental transformation of China's economic development mode into one of sustainable and high-quality development. In fact, air pollution will not only affect human health but also seriously affect economic growth [17]. From the perspective of firms, on the one hand, haze pollution reduces the labor efficiency of employees [18-21], thus affecting the normal operation of firms. On the other hand, it will have a negative impact on firm development by reducing the market value of firms, the availability of debt financing, government subsidies, and other resources [18,22,23]. However, so far, most of the literature on haze pollution has focused on the impact of haze pollution on the human body, mental health, and daily activities [24-26]. We found that in the literature, there are only a few research studies that examine pollution's impact on TFP. Adetutu et al. [27] used data from European countries to study and found that pollution affects the TFP growth decomposition. Zhao and Gao [28] used Chinese provincial data to study the impact of environmental pollution on TFP and pointed out that environmental emissions have a negative effect on TFP growth. Chen and Chen [29] found that haze pollution significantly reduces China's TFP. The above studies are based on the macro level. Therefore, this paper considers starting from the micro level to study the effect of haze pollution on firm-level TFP.

Based on this, to study the impact of haze pollution on firm-level TFP, this paper uses the data on China's A-share listed companies in Shanghai and Shenzhen Stock Exchanges from 2013 to 2017 and the data released by the China National Environmental Monitoring Centre monitoring the air quality of 74 cities. The research results show that haze pollution and a firm's TFP have a significant negative relationship; that is, the intensification of haze pollution will reduce a firm's TFP. Further analysis found the following: haze pollution would not only directly produce a negative impact on a firm's TFP but also have a negative impact on a firm's TFP by reducing the labor productivity. After a series of robustness tests, the above conclusion is still valid.

The incremental contribution of this paper is as follows: First, haze pollution is included in the research horizon, and the influencing factors of firm-level TFP are expanded. Second, empirical data were used to confirm the negative impact of haze pollution on a firm-level TFP, enriching the literature on the economic consequences of haze pollution. Third, this study reveals the intermediary role of labor productivity on the impact of haze pollution on a firm's TFP and opens the "black box" of haze pollution to reveal how it affects a firm-level TFP.

The rest of this paper is arranged as follows. The second part presents a literature review and research hypotheses. The third part offers the research design. The fourth part discusses the empirical results and the analysis. The fifth part presents a further analysis and an endogeneity problem. The sixth part consists of conclusions and policy implications. 


\section{Literature Review}

\subsection{Research on Haze Pollution and TFP}

Solow, a neoclassical economist, placed TFP into a growth equation with constant returns to scale; this framework thus formed the meaning of TFP. According to the Solow growth theory, TFP is the part of the increase in output caused by factors (such as technological progress, socioeconomic system) other than various production input factors (such as labor, capital, and natural resources). Therefore, TFP is also called the Solow Residual [26].

At present, the research on TFP mainly includes macro and micro research. The macro research is mainly focused on the national, regional, or industrial level, as its aim is to reveal the level of economic and technological development and the sources of TFP growth [30-33]. In the micro research, at the firm level, through estimating and decomposing the firm's TFP, scholars analyze the main factors affecting the firm's TFP. Existing studies have found that the factors that affect the firm's TFP include firm innovation and exports, firm operation decisions, government industrial policies, and capital market development [34,35]. However, most scholars pay attention to the impact of internal environmental factors and the external economic environment on TFP, and few scholars have studied the impact of external natural environment factors on TFP.

In fact, scholars have been concerned about the impact of air pollution on economic development. From the research on the impact of haze pollution on firms, it can be seen that air pollution such as haze will significantly reduce the value of firms. Haze pollution does affect the production and operation of firms. The reasons mainly include two aspects. On the one hand, haze pollution restricts the managers' cognition and decision-making [36,37], the impairment of which may lead them to make wrong decisions on the allocation of production factors. The efficiency of the allocation of factors is closely related to the firm's TFP, and the distortion of the allocation of factors will significantly reduce the firm's TFP [38-41]. On the other hand, haze pollution also affects the financing ability of firms. As an important factor of production, capital is an important backing for a firm that enables it to obtain operating production resources, expand its operating scale, and develop and innovate. Haze pollution affects the firms' financing, production, and operations capacity in a way that is not conducive to the firms' scale expansion and scale efficiency [22]. Finally, the aggravation of haze pollution prompts the public to pay more attention to air quality and the government to formulate policies, which hinder the innovation ability and competitiveness of firms $[42,43]$ and thereby results in a decrease in the level of firm production efficiency.

Therefore, haze pollution will reduce the firm's TFP by affecting environmental regulation, the market value of firms, and the management ability of managers. Based on this, this paper proposes the first hypothesis, namely, the following:

Hypothesis 1. Haze pollution will have a negative impact on a firm's TFP.

\subsection{The Mediating Effect of Labor Productivity on Haze Pollution and TFP}

Previous studies reveal that haze pollution does affect the production and operation of firms and other micro subjects and has negative impacts on the production and operation of firms, but the specific path of haze affecting the firm's TFP is not revealed. Therefore, the following discussion will start from the perspective of the labor force, one of the important production factors in firm production, to analyze the influence mechanism through which haze pollution impacts a firm's TFP.

Haze pollution has been found to have a negative impact on people's psychological and physical health [44-46], so it can reduce the production and the operations of firms by affecting the production efficiency of employees. Labor is one of the important input factors in firm production; improving labor production efficiency is an important way to improve a firm's TFP, and firms invest a great deal of resources to attract high-quality labor. Haze pollution will have a negative impact on the productivity of the working labor force of firms and will also lead to the decline of the attractiveness 
of firms to the labor force [47-49]. On the one hand, air pollution will do harm to people's health. For example, induced asthma, respiratory diseases, skin rashes, and other diseases are harmful to human beings and may even reduce the labor supply [50], thus reducing labor efficiency. High-tech employees especially are more vulnerable to air pollution [48]. On the other hand, haze pollution will cause people to suffer from depression, resulting in the decline of the employees' work efficiency. When haze pollution is serious, people worry about their health, which in turn causes an increase in negative emotions [51-53]. Moreover, severe polluted weather will reduce the number of times people go out, thus reducing their chance of face-to-face communication with others and increasing negative emotions [54]. When individuals are immersed in emotions and unable to devote themselves to their work, employees are prone to anti-production behaviors, which adversely affect the performance of firms [55]. Beck et al. [56] found in their study that the more severe the depression is, the greater the labor loss, because the depressed patients are unable to think and carry out their work properly, their working ability is impaired, and their work output is greatly reduced. Therefore, for firms, haze pollution will affect the physical and mental health of employees and reduce their labor efficiency, resulting in reduced work output.

The above analysis demonstrates that the aggravation of haze pollution may reduce the labor productivity of firms and thus reduce the firm's TFP. Labor productivity plays an intermediary role in the influence of haze pollution on the firm's TFP. Based on the above analysis, the second hypothesis of this paper is proposed:

Hypothesis 2. Labor productivity plays an intermediary role between haze pollution and a firm's TFP; that is, haze pollution will reduce a firm's TFP by reducing the labor productivity of firms.

\section{Research Design}

\subsection{Sample Selection}

In this paper, the data of China's A-share listed companies in Shanghai and Shenzhen Stock Exchanges from 2013 to 2017 and the data from the 74-city air quality monitoring report released by the China National Environmental Monitoring Centre were used for research. In the process of sample selection, the following samples are excluded: first, listed companies that issue B shares and $\mathrm{H}$ shares at the same time; second, financial listed companies; and third, listed companies with incomplete data. A total of 7328 sample data observations were obtained. For the sample data in this paper, Table 1 reports the screening process and the sample number. STATA14 was used to regress the models of the paper.

Table 1. Selection.

\begin{tabular}{lc}
\hline \multicolumn{1}{c}{ Item } & $\mathbf{N}$ \\
\hline All data of listed companies in 74 cities of CSMAR database from 2013 to 2017 & 11,208 \\
\hline Less: the data of b-share listed companies & $(511)$ \\
\hline data of listed financial companies & $(349)$ \\
\hline incomplete data of listed companies & $(3020)$ \\
\hline Final sample & 7328 \\
\hline
\end{tabular}

\subsection{Model}

\subsubsection{Model Construction}

In this study, the explanatory variable haze pollution not only directly impacts the explained variable TFP, but also, through labor productivity, has an indirect negative impact on a firm's TFP. Therefore, the mediating method of Baron and Kenny [57] was used in this paper to carry out the regression of the hypotheses. The method requires four regression tests. First, it is necessary to test whether the explanatory variables are related to the explained variable, which is the prerequisite to 
determine whether there is a mediating effect. If relevant, there may be a mediating effect. Second, test whether the explanatory variables are correlated with the mediating variable, and the mediating variable is correlated with the explained variable. If the explanatory variables are related to the mediating variable and the mediating variable is related to the explained variable, then the explanatory variables can influence the explained variable through the mediating variable. Third, test whether the explained variable is related to the explanatory variables and the mediating variable. When the coefficient before the mediating variable is significant, and the coefficient before the explanatory variable is significant, it is a partial mediating effect; otherwise, it is a complete mediating effect. Moreover, this paper conducted Hausman's test on the data and found that the fixed effect was better.

To test the hypothesis in this paper, the following model is constructed by referring to the above analysis method of a mediation model:

$$
\begin{aligned}
& \text { TFP_LP } i t=\alpha_{0}+\alpha_{1} P_{2.5 i t-1}+\alpha_{2} \text { Prf }_{i t}+\alpha_{3} L e v_{i t}+\alpha_{4} \text { Grow }_{i t}+\alpha_{5} \text { Btm }_{i t}+\alpha_{6} L C_{i t}+\alpha_{7} S h 1_{i t}+ \\
& \alpha_{8} S O E_{i t}+\alpha_{9} G D P_{i t}+\alpha_{10} F D I_{i t}+\varepsilon_{1} \\
& \text { Labor }_{i t}=\beta_{0}+\beta_{1} \text { PM }_{2.5 i t-1}+\beta_{2} \operatorname{Prf}_{i t}+\beta_{3} L_{e v} v_{i t}+\beta_{4} \text { Grow }_{i t}+\beta_{5} \text { Btm }_{i t}+\beta_{6} L C_{i t}+\beta_{7} S_{h 1} 1_{i t}+\beta_{8} S O E_{i t} \\
& +\beta_{9} G D P_{i t}+\beta_{10} F D I_{i t}+\varepsilon_{2} \\
& \text { TFP_LP } P_{i t}=\gamma_{0}+\gamma_{1} \text { Labor }_{i t}+\gamma_{2} \text { Prf }_{i t}+\gamma_{3} L e v_{i t}+\gamma_{4} \text { Grow }_{i t}+\gamma_{5} \text { Btm }_{i t}+\gamma_{6} L C_{i t}+\gamma_{7} S_{1} 1_{i t}+\gamma_{8} S O E_{i t}+ \\
& \gamma_{9} G D P_{i t}+\gamma_{10} F D I_{i t}+\varepsilon_{3}
\end{aligned}
$$

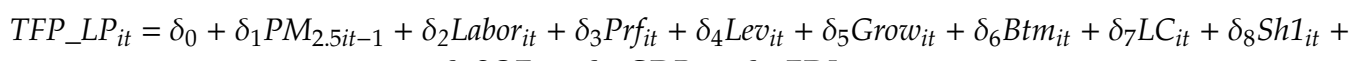

$$
\begin{aligned}
& \delta_{9} S O E_{i t}+\delta_{10} G D P_{i t}+\delta_{11} F D I_{i t}+\varepsilon_{4}
\end{aligned}
$$

In (M1)-(M4), TFP_LP $i$ represents the TFP calculated by the LP method of the firm $i$ at the end of year t. $P M_{2.5 i t-1}$ indicates the concentration degree of haze and takes the annual average monitoring concentration value of $\mathrm{PM}_{2.5}$ in the air in the location of firm $i$ as the proxy variable, which is calculated from the monitoring data released by the China National Environmental Monitoring Centre. Considering the lagging effect of the policy and the fact that employees themselves will take preventive measures to deal with haze pollution, this paper lagged $\mathrm{PM}_{2.5}$ data for one year. Labor $i$ refers to the labor productivity of the firm $i$ at the end of year $t$. Other control variables are defined in Table 2.

Table 2. Variable Definition.

\begin{tabular}{lll}
\hline \multicolumn{1}{c}{ Variable } & \multicolumn{1}{c}{ Description } & \multicolumn{1}{c}{ Description } \\
\hline$T F P_{-} L P_{i t}$ & Firm's total factor productivity (TFP) & TFP estimated by LP method of firm $i$ at the end of year $t$ \\
\hline$T F P_{-} O P_{i t}$ & Firm's TFP & TFP estimated by OP method of firm $i$ at the end of year $t$ \\
\hline$P M_{2.5 i t-1}$ & Haze pollution & $\begin{array}{l}\text { Annual mean value of } \mathrm{PM}_{2.5} \text { monthly concentration monitoring } \\
\text { data for firm's location }\end{array}$ \\
\hline$P M_{c 2.5 i t-1}$ & Haze pollution & $\begin{array}{l}\text { According to the satellite data extracted from Columbia University, } \\
\text { annual mean value of } \mathrm{PM}_{2.5} \text { monthly concentration monitoring data } \\
\text { for firm's location }\end{array}$ \\
\hline$L a b o r_{i t}$ & Labor productivity & ln (revenue/staff average) of firm $i$ at the end of year $t$ \\
\hline$P r f_{i t}$ & Profitability & Total year-end Profits/total assets \\
\hline$L e v_{i t}$ & Asset-liability ratio & Total liabilities/total assets \\
\hline$G r o w i t$ & Revenue growth rate & Operating income growth rate of firm $i$ at the end of year $t$ \\
\hline$B t m_{i t}$ & Book-to-market ratio & The ratio of book value to market value of firm $i$ at the end of year $t$ \\
\hline$L C_{i t}$ & Labor cost & Cash paid to and on behalf of employees/number of employees \\
\hline$S h 1_{i t}$ & $\begin{array}{l}\text { Shareholding ratio of the largest } \\
\text { shareholder }\end{array}$ & $\begin{array}{l}\text { Shareholding ratio of the largest shareholder of firm } i \text { at the end of } \\
\text { year } t\end{array}$ \\
\hline$S O E_{i t}$ & Firm nature & Equal to 1 if the firm is state-owned, 0 otherwise \\
\hline$F D I_{i t}$ & Regional opening level & $\begin{array}{l}\text { The actual use of foreign capital accounted for the proportion of } \\
\text { GDP at the end of year } t\end{array}$ \\
\hline$G D P_{i t}$ & Degree of urban development & $\begin{array}{l}\text { Real GDP per person in the city where the firm } i \text { is located at the end } \\
\text { of year } t\end{array}$ \\
\hline
\end{tabular}


According to the mediation model of Baron and Kenny [57], if $\alpha_{1}$ in M1 is significant and negative in the regression results, it indicates that haze pollution will reduce a firm's TFP, which proves hypothesis 1 and also indicates that there may be a mediation effect. In M2 and M3, if $\beta_{1}$ and $\gamma_{1}$ are significant, it indicates that haze pollution can have an impact on a firm's TFP through labor productivity. In M4, if $\delta_{1}$ and $\delta_{2}$ are both significant, it indicates that haze pollution can have an impact on a firm's TFP through the channel of labor productivity, which also proves hypothesis 2 . In the above method, the total effect of haze pollution on a firm's TFP is $\alpha_{1}$, the direct effect is $\delta_{1}$, and the indirect effect is $\beta_{1}^{*} \gamma_{1}$ or $\left(\alpha_{1}-\delta_{1}\right)$.

\subsubsection{Variable Definition}

For the estimation of TFP, the commonly used methods are the consistent semiparametric estimation method (OP method) by Olley and Pakes [58] and the method (LP method) used by Levinsohn and Petrin [59]. Therefore, this paper will also use these two methods to estimate the firm's TFP: the semiparametric methods represented by the LP method and the OP method are adopted to estimate the firm's TFP. A semiparametric estimation is a combination of a nonparametric estimation and a parametric estimation. The use of a nonparametric estimation denotes that we know nothing about the regression function and need a large number of samples. The parameter estimation is used to calculate the model parameters with the input and output data of the system when the system model is known. This paper adopts the LP method to estimate the firm's TFP. Referring to the practices of $\mathrm{Lu}$ [60], data such as the added value of the main business of the listed companies, the number of employees, and the input of intermediate products will be used to measure firm output, labor input, and the input of intermediate products. Among them, the net value of fixed assets, project materials, the projects under construction, and fixed assets liquidation are selected to depict the capital status of firms.

The average concentration of $\mathrm{PM}_{2.5}$ in 74 cities over 12 months each year, published by the China National Environmental Monitoring Centre (data source: http://www.cnemc.cn/jcbg/kqzlzkbg/), was used as an indicator of haze pollution $\left(\mathrm{PM}_{2.5}\right)$. China National Environmental Monitoring Centre is affiliated with the Ministry of Ecology and Environment of the People's Republic of China. Every year, the Centre will compile various environmental monitoring reports, such as a national environmental quality bulletin, a China environmental quality annual report and an environmental statistical annual report, which provide decision-making support for environmental management policy planning, environmental quality assessment rankings, and transfer payments for national key ecological function zones. The Centre provides data on the air quality in 74 cities, which include China's first-tier cities, second-tier cities, and some third-tier cities, and among which $75.37 \%$ of the A-share listed companies on Shanghai and Shenzhen are registered. Therefore, the China National Environmental Monitoring Centre is selected as the source of the haze data in this paper. Considering the lagging effect of the policy and the fact that employees themselves will take preventive measures to deal with haze pollution, this paper lagged $\mathrm{PM}_{2.5}$ data for a year. Labor productivity is expressed as the ratio of the year's revenue to the average number of employees.

In addition, on the basis of a theoretical analysis, this paper refers to the research of Yang et al. [61] and İmrohoroğlu and Tüzel [62]. The following control variables were selected: the Profitability of firms $\left(P r f_{i t}\right)$; a firm's solvency $\left(L e v_{i t}\right)$; growth ability $\left(G r o w i t, B t m_{i t}\right)$; firm labor costs $\left(L C_{i t}\right)$; the corporate governance structure (the largest shareholder's shareholdings, $S h 1_{i t}$; the $S O E_{i t}$ ownership form), and the model and control of regional economic factors (regional opening level, FDI it; urban GDP per capita, $G D P_{i t}$ ). The firm's financial data was obtained from the CSMAR database (URL of the CSMAR database: http://www.gtarsc.com/\#/index) and the China Statistical Yearbook. The CSMAR database draws on the successful experience of internationally renowned databases, such as the University of Chicago's CRSP, Standard \& Poor's Compustat, the New York Stock Exchange's TAQ, Thomson, and GSIOnline. The database is the largest and most accurate financial and economic database in China and consists of 8 series of stocks, funds, bonds, financial derivatives, listed companies, economy, 
industry, high-frequency data, and personalized data services. Regional economic data was obtained from the China City Statistical Yearbook. The definitions and numerical calculations of each variable are shown in Table 2.

\section{Empirical Results and Analysis}

\subsection{Descriptive Statistics}

Table 3 reports the description statistics of the main variables. The average value of TFP_LP it of the listed firms is 16.177 , the median is 16.051 , and the standard deviation is 1.122 . The $P M_{2.5 i t-1}$ concentration is the lowest at 20.890 and the highest at 160.070 , with an average value of 57.482 and a standard deviation of 20.145. The average value of the labor productivity of firms is 13.836 ; the minimum value is 9.325 , the maximum value is 18.951 , and the standard deviation is 0.919 . The other variables are shown in the table.

Table 3. Description Statistics.

\begin{tabular}{|c|c|c|c|c|c|c|}
\hline Variable & $\mathbf{N}$ & Mean & Std & Min & Med & Max \\
\hline$T F P_{-} L P_{i t}$ & 7328 & 16.176 & 1.124 & 11.585 & 16.051 & 20.945 \\
\hline$T F P_{-} O P_{i t}$ & 7328 & 12.669 & 0.875 & 8.209 & 12.530 & 17.726 \\
\hline$P M_{2.5 i t-1}$ & 7328 & 3.996 & 0.368 & 3.039 & 4.006 & 5.076 \\
\hline$P M_{c 2.5 i t-1}$ & 7328 & 3.696 & 0.369 & 2.407 & 3.786 & 4.460 \\
\hline Labor $_{\text {it }}$ & 7328 & 13.834 & 0.917 & 9.325 & 13.708 & 18.951 \\
\hline $\operatorname{Prf}_{i t}$ & 7328 & 0.036 & 0.148 & -6.708 & 0.027 & 5.369 \\
\hline$L e v_{i t}$ & 7328 & 0.423 & 0.215 & 0.014 & 0.409 & 3.262 \\
\hline Grow $_{\text {it }}$ & 7328 & 0.531 & 1.341 & -0.748 & 0.195 & 10.545 \\
\hline $\mathrm{Btm}_{i t}$ & 7328 & 0.751 & 0.850 & 0.008 & 0.472 & 12.048 \\
\hline$L C_{i t}$ & 7328 & 12.987 & 25.004 & 0.000 & 10.422 & 1492.784 \\
\hline $\operatorname{Sh} 1_{i t}$ & 7328 & 36.225 & 15.348 & 3.390 & 34.384 & 89.409 \\
\hline$S O E_{i t}$ & 7328 & 0.323 & 0.468 & 0 & 0 & 1 \\
\hline$F D I_{i t}$ & 7328 & 2.340 & 0.334 & 0.822 & 2.377 & 2.913 \\
\hline$G D P_{i t}$ & 7328 & 0.005 & 0.003 & 0.000 & 0.005 & 0.027 \\
\hline
\end{tabular}

\subsection{Regression Results}

For models (M1)-(M4), the regression results are shown in Table 4. After controlling a series of potential influencing variables, the regression coefficient of $\mathrm{PM}_{2.5 i t-1}$ in $\mathrm{M} 1$ is -0.529 , which is significant at the level of $1 \%$, indicating that haze pollution will significantly reduce a firm's TFP. The test results verify Hypothesis 1. In Table 4, the influence coefficient of M2 haze pollution on the labor productivity of firms is -0.236 , which is significant at the level of $1 \%$; that is, for every $1 \%$ increase in haze pollution, labor productivity will decline by $0.236 \%$, indicating that the increase in haze pollution will reduce the labor productivity of employees. In M3, the coefficient of labor productivity on a firm's TFP is 0.825 , which is significant at the level of $1 \%$, indicating that for every $1 \%$ increase in labor productivity, a firm's TFP will rise by $0.825 \%$. In M4, the coefficient of haze pollution on a firm's TFP is -0.336 , which is significant at the level of $1 \%$. This also indicates that in the mediation effect test, haze pollution has a direct effect on a firm's TFP, and the direct effect is $\delta_{1}=-0.336$. The analysis of the intermediary effect shows that in (M1)-(M4), the total effect of haze pollution on a firm's TFP is $\alpha_{1}=-0.529$, the direct effect is $\delta_{1}=-0.336$, and the indirect effect of haze pollution on a firm's TFP through reducing employees' labor productivity is -0.195 (in the mediating effect, the mediating effect of labor productivity is $\beta_{1}^{*} \gamma_{1}$, that is $\left.-0.236 \times 0.825\right)$; that is, the mediation effect is -0.195 . 
Table 4. Result of Mediation Model Regression.

\begin{tabular}{|c|c|c|c|c|}
\hline \multirow{2}{*}{ Variable } & M1 & M2 & M3 & M4 \\
\hline & $T F P_{-} L P_{i t}$ & Labor $_{i t}$ & $T F P_{-} L P_{i t}$ & $T F P_{-} L P_{i t}$ \\
\hline \multirow{2}{*}{$P M_{2.5 i t-1}$} & $-0.529^{* * *}$ & $-0.236^{* * *}$ & & $-0.336^{* * *}$ \\
\hline & $(-8.62)$ & $(-4.04)$ & & $(-8.46)$ \\
\hline \multirow{2}{*}{ Labor $_{i t}$} & & & $0.825^{* * *}$ & $0.819^{* * * *}$ \\
\hline & & & (30.09) & $(30.02)$ \\
\hline \multirow{2}{*}{$\operatorname{Prf}_{i t}$} & -0.079 & 0.058 & $-0.133 *$ & $-0.127^{*}$ \\
\hline & $(-1.14)$ & $(0.67)$ & $(-1.96)$ & $(-1.86)$ \\
\hline \multirow{2}{*}{$\operatorname{Lev}_{i t}$} & 0.212 & -0.223 & $0.409 * * *$ & $0.395^{* * * *}$ \\
\hline & $(1.32)$ & $(-1.26)$ & $(5.27)$ & $(5.16)$ \\
\hline \multirow{2}{*}{ Grow $_{i t}$} & 0.014 & $0.025^{* * *}$ & -0.007 & -0.007 \\
\hline & (1.41) & $(2.90)$ & $(-1.36)$ & $(-1.34)$ \\
\hline \multirow{2}{*}{$B t m_{i t}$} & $0.148^{* * *}$ & $0.109^{* * *}$ & $0.059^{* *}$ & $0.059 * *$ \\
\hline & (3.27) & (3.53) & (2.45) & (2.50) \\
\hline \multirow{2}{*}{$L C_{i t}$} & $0.001 * *$ & 0.0002 & $0.001^{* *}$ & $0.001 *$ \\
\hline & $(2.16)$ & $(0.20)$ & (2.02) & (1.92) \\
\hline \multirow{2}{*}{$\operatorname{Sh} 1_{i t}$} & 0.001 & $0.002 * *$ & -0.001 & -0.001 \\
\hline & (1.33) & $(2.36)$ & $(-1.59)$ & $(-1.33)$ \\
\hline \multirow{2}{*}{$S O E_{i t}$} & 0.108 & 0.034 & 0.066 & 0.080 \\
\hline & (1.46) & $(0.52)$ & (1.27) & (1.50) \\
\hline \multirow{2}{*}{$G D P_{i t}$} & $0.378^{* * *}$ & $0.406^{* * *}$ & $0.350^{* * *}$ & 0.046 \\
\hline & (5.33) & $(5.83)$ & (9.13) & $(0.94)$ \\
\hline \multirow{2}{*}{$F D I_{i t}$} & $-6.289 *$ & -0.165 & $-7.853^{* * *}$ & $-6.154^{* * *}$ \\
\hline & $(-1.65)$ & $(-0.05)$ & $(-3.30)$ & $(-2.63)$ \\
\hline \multirow{2}{*}{ Constant } & $17.143^{* * *}$ & $13.730^{* * *}$ & $3.783 * * *$ & $5.902 * * *$ \\
\hline & $(45.45)$ & $(38.04)$ & (11.11) & $(13.98)$ \\
\hline Industry & control & control & control & control \\
\hline Region & control & control & control & control \\
\hline adj. $R^{2}$ & 0.172 & 0.092 & 0.701 & 0.708 \\
\hline $\mathrm{F}$ & 52.08 & 24.07 & 195.7 & 190.4 \\
\hline
\end{tabular}

Note: ${ }^{* *},{ }^{* *}$ and * represent statistically significant at the $1 \%, 5 \%$, and $10 \%$ levels, respectively; brackets are $t$ values.

A further analysis of Table 4 shows that the coefficient of the firm's growth capacity $\left(B t m_{i t}, G^{\prime} r w_{i t}\right)$ is significantly positive. This may be due to the increase of operating income, which generates sufficient funds for firms to expand production and improve their TFP. Regarding the corporate structure, the coefficient of Shrcr1 is positive, which could be explained by the fact that a concentration of stock ownership reduces the irrational behavior of firms and greatly reduces the efficiency loss between shareholders and agents, thereby proving beneficial for the production and operation of firms. Among the factors controlling regional development, the coefficient of regional opening level $\left(F D I_{i t}\right)$ is significantly negative, indicating that the improvement of regional opening level is not conducive to improving firm production efficiency. At the same time, the increase of regional gross domestic product $\left(G D P_{i t}\right)$ can explain the regional consumption capacity strengthening, which is conducive to a firm's production, sales, the expansion of production, the acquisition of a scale economy, and the promotion of firm's TFP.

\section{Further Analysis and Endogeneity Problem}

\subsection{Robustness Test}

The empirical results of this paper show that the aggravation of haze pollution has an inhibitory effect on a firm' s TFP and that labor productivity plays a partial intermediary role in the relationship 
between haze pollution and TFP. The robustness of the three relationships needs to be verified. Therefore, this paper adopts different methods for the robustness test.

\subsubsection{Change the Measurement Method of Haze Pollution}

In order to ensure the robustness of the model from the perspective of explanatory variables, this paper uses the air pollution data published by Columbia University to replace the data published by the China National Environmental Monitoring Centre. Both the data of Columbia University and the data of the China National Environmental Monitoring Centre monitor the $\mathrm{PM}_{2.5}$ situation in the air when monitoring environmental quality. The difference of the two is that the calculation method, the average time, and concentration limit. The Centre adopts the hourly concentration value of $\mathrm{PM}_{2.5}$ monitored for $24 \mathrm{~h}$, and the 24-h average concentration limit is not more than $75 \mu \mathrm{g} / \mathrm{m}^{3}$; Columbia University adopts the hourly concentration value of $\mathrm{PM}_{2.5}$ that is monitored for an average of $12 \mathrm{~h}$, and the 24-h average concentration limit is less than $12 \mu \mathrm{g} / \mathrm{m}^{3}$. As the Centre and Columbia University set different $\mathrm{PM}_{2.5}$ concentration limits, the $\mathrm{PM}_{2.5}$ index calculated from this is naturally different. Therefore, it is meaningful to use Columbia University data to replace the data of the China National Environmental Monitoring Centre. If it is still significant after the replacement, it indicates that our models are robust. The hypotheses, namely, those tested in models (M1)-(M4), were repeatedly tested by replacing $\mathrm{PM}_{2.5 i t-1}$ with $\mathrm{PM}_{c 2.5 i t-1}$, and the regression results are shown in Table 5 .

Table 5. Robustness Test 1 -Replace $\mathrm{PM}_{2.5}$ Data.

\begin{tabular}{|c|c|c|c|c|}
\hline \multirow{2}{*}{ Variable } & M1 & M2 & M3 & M4 \\
\hline & $T F P_{-} L P_{i t}$ & Labor $_{i t}$ & $T F P_{-} L P_{i}$ & $\left(T F P_{-} L P_{i t} F P_{-} O P\right)$ \\
\hline \multirow{2}{*}{$P M_{c 2.5 i t-1}$} & $-0.183^{* * *}$ & $-0.153^{* * *}$ & & $-0.057^{* *}$ \\
\hline & $(-3.82)$ & $(-3.25)$ & & $(-2.02)$ \\
\hline \multirow{2}{*}{ Labor $_{i t}$} & & & $0.825^{* * *}$ & $0.827^{* * *}$ \\
\hline & & & (30.09) & $(28.82)$ \\
\hline \multirow{2}{*}{$\operatorname{Prf} f_{i t}$} & -0.104 & 0.065 & $-0.133 *$ & $-0.158^{*}$ \\
\hline & $(-1.48)$ & $(0.56)$ & $(-1.96)$ & $(-1.76)$ \\
\hline \multirow{2}{*}{$L e v_{i t}$} & 0.245 & -0.201 & $0.409^{* * *}$ & $0.411^{* * *}$ \\
\hline & $(1.52)$ & $(-1.17)$ & $(5.27)$ & $(5.31)$ \\
\hline \multirow{2}{*}{ Grow $_{\text {it }}$} & $0.016^{*}$ & $0.027^{* * *}$ & -0.007 & -0.006 \\
\hline & (1.65) & (3.24) & $(-1.36)$ & $(-1.20)$ \\
\hline \multirow{2}{*}{ Btm $_{i t}$} & $0.143^{* * *}$ & $0.103^{* * *}$ & $0.059 * *$ & $0.058^{* *}$ \\
\hline & (3.31) & $(3.72)$ & $(2.45)$ & $(2.37)$ \\
\hline \multirow{2}{*}{$L C_{i t}$} & $0.020^{* * *}$ & $0.026^{* * *}$ & $0.001^{* *}$ & -0.001 \\
\hline & (7.19) & $(7.88)$ & $(2.02)$ & $(-0.41)$ \\
\hline \multirow{2}{*}{$\operatorname{Sh} 1_{i t}$} & 0.001 & $0.002 * *$ & -0.001 & -0.001 \\
\hline & $(1.00)$ & $(2.12)$ & $(-1.59)$ & $(-1.57)$ \\
\hline \multirow{2}{*}{$S O E_{i t}$} & 0.103 & 0.046 & 0.066 & 0.064 \\
\hline & $(1.42)$ & $(0.74)$ & $(1.27)$ & $(1.24)$ \\
\hline \multirow{2}{*}{$G D P_{i t}$} & $0.656^{* * *}$ & $0.382^{* * *}$ & $0.350^{* * *}$ & $0.339^{* * *}$ \\
\hline & $(11.64)$ & $(6.29)$ & (9.13) & $(7.80)$ \\
\hline \multirow{2}{*}{$F D I_{i t}$} & $-7.940^{* *}$ & -0.137 & $-7.853^{* * *}$ & $-7.827^{* * *}$ \\
\hline & $(-2.07)$ & $(-0.04)$ & $(-3.30)$ & $(-3.28)$ \\
\hline \multirow{2}{*}{ Constant } & $14.835^{* * *}$ & $13.091^{* * *}$ & $3.783^{* * *}$ & $4.009^{* * *}$ \\
\hline & $(60.65)$ & (51.14) & (11.11) & $(9.80)$ \\
\hline Industry & control & control & control & control \\
\hline Region & control & control & control & control \\
\hline adj. $R^{2}$ & 0.185 & 0.146 & 0.701 & 0.699 \\
\hline F & 51.16 & 32.56 & 195.7 & 184.9 \\
\hline
\end{tabular}

Note: ${ }^{* * *}, * *$ and ${ }^{*}$ represent statistically significant at the $1 \%, 5 \%$, and $10 \%$ levels, respectively; brackets are $t$ values. 
After controlling a series of potential influencing variables, the regression coefficient of $\mathrm{PM}_{c 2.5 i t-1}$ in $\mathrm{M} 1$ is -0.183 , which is significant at the level of $1 \%$, indicating that haze pollution will significantly reduce a firm's TFP. The test results verify Hypothesis 1 . In Table 5, the influence coefficient of M2 haze pollution on the labor productivity of firms is -0.153 , which is significant at the level of $1 \%$. For every $1 \%$ increase in haze pollution, labor productivity will decline by $0.153 \%$, indicating that the increase in haze pollution will reduce the labor productivity of employees. In M3, the coefficient of labor productivity on a firm's TFP is 0.825 , which is significant at the level of $1 \%$, indicating that for every $1 \%$ increase in labor productivity, a firm's TFP will rise by $0.825 \%$. In M4, it can be seen that the coefficient of haze pollution on a firm's TFP is -0.336 , which is significant at the level of $1 \%$. This also indicates that in the mediation effect test, haze pollution has a direct effect on a firm's TFP, and the direct effect is $\delta_{1}=-0.077$. The analysis of the intermediary effect shows that in (M1)-(M4), the total effect of haze pollution on a firm's TFP is $\alpha_{1}=-0.336$, the direct effect is $\delta_{1}=-0.057$, and the indirect effect of haze pollution on a firm's TFP through reducing employees' labor productivity is -0.126 ; that is, the mediation effect is $-0.126(=-0.153 \times 0.825)$.

\subsubsection{Change the Measurement of TFP}

In order to ensure the robustness of the model from the perspective of the explained variable, the OP method was adopted to calculate the TFP of each firm as the explained variable. A fixed effect regression was carried out again for the model to test the two hypotheses in this paper. The results are shown in Table 6. As seen from Table 6, the coefficient of haze pollution in M1 is -0.303 , which is significant at the level of $1 \%$, indicating that haze pollution will significantly reduce a firm's TFP. The test results verify Hypothesis 1 . In Table 6, the influence coefficient of M2 haze pollution on the labor productivity of firms is -0.236 , which is significant at the level of $1 \%$. For every $1 \%$ increase in haze pollution, labor productivity will decline by $0.236 \%$, indicating that the increase in haze pollution will reduce the labor productivity of employees. In M3, the coefficient of labor productivity on the firm's TFP is 0.876 , which is significant at the level of $1 \%$, indicating that for every $1 \%$ increase in labor productivity, a firm's TFP will rise by $0.876 \%$. In M4, the coefficient of haze pollution on a firm's TFP is -0.097 , which is significant at the level of $1 \%$. This also indicates that in the mediation effect test, haze pollution has a direct effect on a firm's TFP, and the direct effect is $\delta_{1}=-0.097$. The coefficient of labor productivity on a firm's TFP is 0.874 , which is significant at the level of $1 \%$, indicating that for every $1 \%$ increase in labor productivity, a firm's TFP will rise by $0.874 \%$.The analysis of the intermediary effect shows that in M1-M3, the total effect of haze pollution on a firm's TFP is $\alpha_{1}=-0.303$, the direct effect is $\delta_{1}=-0.097$, and the indirect effect of haze pollution on a firm's TFP through reducing employees' labor productivity is -0.085 ; that is, the mediation effect is -0.0206 .

Table 6. Robustness Test 2-Replace TFP_LP Data.

\begin{tabular}{|c|c|c|c|c|}
\hline \multirow{2}{*}{ Variable } & M1 & M2 & M3 & M4 \\
\hline & $T F P_{-} O P_{i t}$ & Labor $_{i t}$ & $T F P_{-} O P_{i t}$ & $T F P \_O P_{i t}$ \\
\hline \multirow{2}{*}{$P M_{2.5 i t-1}$} & $-0.303^{* * *}$ & $-0.236^{* * *}$ & & $-0.097^{* * *}$ \\
\hline & $(-5.37)$ & $(-4.04)$ & & $(-3.98)$ \\
\hline \multirow{2}{*}{ Labor $_{i t}$} & & & $0.876^{* * *}$ & $0.874^{* * *}$ \\
\hline & & & $(51.22)$ & $(51.25)$ \\
\hline \multirow{2}{*}{$\operatorname{Prf} f_{i t}$} & 0.037 & 0.058 & -0.016 & -0.014 \\
\hline & $(0.49)$ & $(0.67)$ & $(-0.42)$ & $(-0.36)$ \\
\hline \multirow{2}{*}{$\operatorname{Lev}_{i t}$} & -0.085 & -0.223 & $0.114^{* *}$ & $0.110^{* *}$ \\
\hline & $(-0.58)$ & $(-1.26)$ & $(2.56)$ & $(2.49)$ \\
\hline \multirow{2}{*}{ Grow $_{i t}$} & 0.012 & $0.025^{* * *}$ & $-0.011^{* * *}$ & $-0.011^{* * * *}$ \\
\hline & (1.28) & $(2.90)$ & $(-2.82)$ & $(-2.82)$ \\
\hline \multirow{2}{*}{$\mathrm{Btm}_{i t}$} & $0.097^{* * *}$ & $0.109^{* * *}$ & 0.003 & 0.002 \\
\hline & (3.05) & (3.53) & $(0.29)$ & $(0.29)$ \\
\hline
\end{tabular}


Table 6. Cont.

\begin{tabular}{ccccc}
\hline \multirow{2}{*}{ Variable } & M1 & M2 & M3 & M4 \\
\cline { 2 - 5 } & TFP_OP $_{i t}$ & Labor $_{i t}$ & TFP_OP $_{i t}$ & TFP_OP $_{\text {it }}$ \\
\hline \multirow{2}{*}{$L C_{i t}$} & $0.003^{* * *}$ & 0.000 & $0.003^{* * *}$ & $0.003^{* * *}$ \\
\cline { 2 - 5 } & $(3.32)$ & $(0.20)$ & $(7.67)$ & $(7.63)$ \\
\hline \multirow{2}{*}{$S h 1_{i t}$} & $0.002^{* *}$ & $0.002^{* *}$ & -0.000 & 0.000 \\
\cline { 2 - 5 } & $(2.36)$ & $(2.36)$ & $(-0.09)$ & $(0.01)$ \\
\hline \multirow{2}{*}{$S O E_{i t}$} & $-0.162^{* *}$ & 0.034 & $-0.195^{* * *}$ & $-0.192^{* * *}$ \\
\cline { 2 - 5 } & $(-2.44)$ & $(0.52)$ & $(-8.10)$ & $(-7.83)$ \\
\hline \multirow{2}{*}{$G D P_{i t}$} & $0.379^{* * *}$ & $0.406^{* * *}$ & $0.112^{* * *}$ & 0.024 \\
\cline { 2 - 5 } & $(5.94)$ & $(5.83)$ & $(5.75)$ & $(0.81)$ \\
\hline \multirow{2}{*}{$F D I_{i t}$} & -2.850 & -0.165 & $-3.198^{* * *}$ & $-2.705^{* * *}$ \\
\hline \multirow{2}{*}{ Constant } & $(-0.84)$ & $(-0.05)$ & $(-2.65)$ & $(-2.27)$ \\
\cline { 2 - 5 } & $12.912^{* * *}$ & $13.730^{* * *}$ & 0.295 & $0.9100^{* * *}$ \\
\hline Industry & $(37.74)$ & $(38.04)$ & $(1.36)$ & $(3.56)$ \\
\hline Region & control & control & control & control \\
\hline adj. R $^{2}$ & control & control & control & control \\
\hline F & 0.126 & 0.092 & 0.830 & 0.831 \\
\hline & 32.93 & 24.07 & 420.9 & 386.4 \\
\hline
\end{tabular}

Note: ${ }^{* * *},{ }^{* *}$ represent statistically significant at the $1 \%, 5 \%$ levels, respectively; brackets are $t$ values.

\subsubsection{Eliminate Firms with Inconsistent Office and Registered Places}

To avoid the wrong matching of haze data, an examination of the data was conducted to determine if the offices of the listed companies were located overseas or were not consistent with the registration places. Therefore, in order to improve the robustness of the regression results, in this paper, the firms whose registered places and offices were inconsistent were eliminated, and a total of 6926 sample data observations was obtained. Then, the model was regressed again. The regression results are shown in Table 7.

Table 7. Robustness Test 3—Delete Address Inconsistent Data.

\begin{tabular}{|c|c|c|c|c|}
\hline \multirow{2}{*}{ Variable } & M1 & M2 & M3 & M4 \\
\hline & $T F P_{-} L P_{i t}$ & Labor $_{i t}$ & $T F P_{-} L P_{i t}$ & $T F P_{-} L P_{i t}$ \\
\hline \multirow{2}{*}{$P M_{2.5 i t-1}$} & $-0.456^{* * *}$ & $-0.174^{* * *}$ & & $-0.319^{* * *}$ \\
\hline & $(-7.91)$ & $(-3.09)$ & & $(-8.17)$ \\
\hline \multirow{2}{*}{ Labor $_{i t}$} & & & $0.793^{* * *}$ & $0.788^{* * *}$ \\
\hline & & & $(27.32)$ & $(27.31)$ \\
\hline \multirow{2}{*}{$\operatorname{Prf}_{i t}$} & -0.045 & 0.105 & $-0.133 *$ & -0.128 * \\
\hline & $(-0.57)$ & $(1.15)$ & $(-1.75)$ & $(-1.70)$ \\
\hline \multirow{2}{*}{$L e v_{i t}$} & 0.239 & -0.213 & $0.417^{* * *}$ & $0.407^{* * *}$ \\
\hline & (1.30) & $(-1.02)$ & $(4.94)$ & $(4.89)$ \\
\hline \multirow{2}{*}{ Grow $_{i t}$} & 0.012 & $0.022 * *$ & -0.006 & -0.006 \\
\hline & $(1.10)$ & $(2.34)$ & $(-1.01)$ & $(-1.01)$ \\
\hline \multirow{2}{*}{ Btm $_{i t}$} & $0.130^{* * *}$ & $0.097^{* * *}$ & $0.054^{* *}$ & $0.054^{* *}$ \\
\hline & $(2.72)$ & (2.96) & $(2.07)$ & (2.11) \\
\hline \multirow{2}{*}{$L C_{i t}$} & $0.001^{* *}$ & 0.000 & $0.001^{* *}$ & $0.001 *$ \\
\hline & $(2.23)$ & $(0.17)$ & $(2.00)$ & $(1.91)$ \\
\hline \multirow{2}{*}{$S h 1_{i t}$} & $0.002 *$ & $0.003^{* * *}$ & $-0.001 *$ & -0.001 \\
\hline & (1.83) & $(2.87)$ & $(-1.74)$ & $(-1.42)$ \\
\hline \multirow{2}{*}{$S O E_{i t}$} & 0.107 & 0.040 & 0.064 & 0.075 \\
\hline & $(1.47)$ & $(0.64)$ & (1.17) & (1.34) \\
\hline
\end{tabular}


Table 7. Cont

\begin{tabular}{|c|c|c|c|c|}
\hline \multirow{2}{*}{ Variable } & M1 & M2 & M3 & M4 \\
\hline & $T F P_{-} L P_{i t}$ & Labor $_{i t}$ & $T F P_{-} L P_{i t}$ & $T F P_{-} L P_{i t}$ \\
\hline \multirow{2}{*}{$G D P_{i t}$} & $0.396^{* * *}$ & $0.431^{* * *}$ & $0.346^{* * *}$ & 0.056 \\
\hline & (5.53) & $(6.12)$ & $(8.74)$ & (1.13) \\
\hline \multirow{2}{*}{$F D I_{i t}$} & -3.269 & 0.699 & $-5.714^{* * *}$ & $-3.820 * *$ \\
\hline & $(-1.11)$ & $(0.22)$ & $(-3.26)$ & $(-2.27)$ \\
\hline \multirow{2}{*}{ Constant } & $16.762 * * *$ & $13.380^{* * *}$ & $4.213^{* * *}$ & $6.215^{* * *}$ \\
\hline & $(45.48)$ & $(37.43)$ & (11.83) & $(13.94)$ \\
\hline Industry & control & control & control & control \\
\hline Region & control & control & control & control \\
\hline adj. $R^{2}$ & 0.172 & 0.089 & 0.172 & 0.696 \\
\hline $\mathrm{F}$ & 50.08 & 22.22 & 50.08 & 181.4 \\
\hline
\end{tabular}

As seen from Table 7, the coefficient of haze pollution in M1 is -0.456 , which is significant at the level of $1 \%$, indicating that haze pollution will significantly reduce a firm's TFP. The test results verify Hypothesis 1. In Table 7, the influence coefficient of M2 haze pollution on the labor productivity of firms is -0.174 , which is significant at the level of $1 \%$. For every $1 \%$ increase in haze pollution, labor productivity will decline by $0.174 \%$, indicating that the increase in haze pollution will reduce the labor productivity of employees. In M3, the coefficient of labor productivity on a firm's TFP is 0.793 , which is significant at the level of $1 \%$, indicating that for every $1 \%$ increase in labor productivity, a firm's TFP will rise by $0.793 \%$. In M4, the coefficient of haze pollution on a firm's TFP is -0.319 , which is significant at the level of $1 \%$. This also indicates that in the mediation effect test, haze pollution has a direct effect on a firm's TFP, and the direct effect is $\delta_{1}=-0.319$. The analysis of the intermediary effect shows that in M1-M4, the total effect of haze pollution on a firm's TFP is $\alpha_{1}=-0.456$, the direct effect is $\delta_{1}=-0.3183$, and the indirect effect of haze pollution on a firm's TFP through reducing employees' labor productivity is -0.1379 ; that is, the mediation effect is $-0.138(=-0.174 \times 0.793)$.

\subsection{Heterogeneity Analysis}

\subsubsection{Industry Heterogeneity}

At present, China is making efforts to improve the quality of its economy and guide its enterprises to take the road of green and sustainable development. The public's concern for the air environment and the government's treatment of pollution both to a certain extent affect the development of firms. At the top of the government's priority list are pollution industries. Heavy-polluting industries may face higher political costs brought by stricter government supervision, more compliance with environmental regulations, and higher operating costs brought by increased financing costs, all of which are not conducive to the improvement of a firm's TFP. Therefore, this paper divides the industries of listed companies into heavy polluting industries and non-heavy polluting industries for heterogeneity analysis. The classification of heavy-polluting industries is mainly based on the following: the "Guidelines for the Industry Classification of Listed Companies (2012 Revision)" formulated by the China Securities Regulatory Commission; the "Classified Management Names of the Environmental Protection Verification Industry of Listed Companies" formulated by the Ministry of Environmental Protection of the People's Republic of China in 2008; and the "Guide for the Environmental Information Disclosure of Listed Companies," which includes 16 heavy polluting industries, including the coal, mining, textile, leather, paper, petrochemical, pharmaceutical, chemical, metallurgy, and thermal power industries. The regression results are shown in Table 8. 
Table 8. Heterogeneity Test 1-Industry Heterogeneity.

\begin{tabular}{|c|c|c|c|c|c|c|c|c|}
\hline & (1) & (2) & (3) & (4) & (5) & (6) & (7) & (8) \\
\hline & \multicolumn{5}{|c|}{ Non-Heavy Polluting } & \multicolumn{3}{|c|}{ Heavy Polluting } \\
\hline Variable & $T F P_{-} L P_{i t}$ & Labor $_{i t}$ & $T F P_{-} L P_{i t}$ & $T F P_{-} L P_{i t}$ & $T F P_{-} L P_{i t}$ & Labor $_{i t}$ & $T F P_{-} L P_{i t}$ & $T F P_{-} L P_{i t}$ \\
\hline \multirow[t]{2}{*}{$P M_{2.5 i t-1}$} & $-0.572 * * *$ & $-0.324^{* * *}$ & & $-0.304^{* * *}$ & $-0.232^{* *}$ & 0.112 & & $-0.317^{* * *}$ \\
\hline & $(-7.98)$ & $(-4.80)$ & & $(-7.00)$ & $(-2.47)$ & (1.11) & & $(-4.22)$ \\
\hline \multirow[t]{2}{*}{ Labor $_{i t}$} & & & $0.835^{* * *}$ & $0.828^{* * *}$ & & & $0.752^{* * *}$ & $0.756^{* * *}$ \\
\hline & & & $(28.35)$ & (28.12) & & & (11.19) & $(11.28)$ \\
\hline \multirow[t]{2}{*}{$P r f_{i t}$} & -0.015 & 0.074 & -0.083 & -0.076 & $-0.210 * *$ & 0.016 & $-0.233^{* * *}$ & $-0.222 * * *$ \\
\hline & $(-0.25)$ & $(0.68)$ & $(-1.22)$ & $(-1.13)$ & $(-2.09)$ & $(0.25)$ & $(-2.76)$ & $(-2.87)$ \\
\hline \multirow[t]{2}{*}{$\operatorname{Lev}_{i t}$} & $0.334^{* *}$ & -0.002 & $0.345^{* * *}$ & $0.335^{* * *}$ & -0.169 & -0.658 & $0.337^{* * *}$ & $0.328^{* * *}$ \\
\hline & (2.33) & $(-0.02)$ & (3.61) & (3.54) & $(-0.54)$ & $(-1.57)$ & (3.35) & (3.34) \\
\hline \multirow[t]{2}{*}{ Grow $_{i t}$} & $0.022 * *$ & $0.028^{* * *}$ & -0.001 & -0.001 & -0.019 & 0.011 & $-0.027^{* * *}$ & $-0.027^{* * *}$ \\
\hline & $(1.97)$ & $(2.80)$ & $(-0.15)$ & $(-0.15)$ & $(-1.11)$ & $(0.65)$ & $(-3.27)$ & $(-3.06)$ \\
\hline \multirow[t]{2}{*}{$B t m_{i t}$} & $0.170^{* * *}$ & $0.138^{* * *}$ & $0.055^{* *}$ & $0.056^{* *}$ & 0.015 & -0.012 & 0.028 & 0.024 \\
\hline & $(3.49)$ & $(4.24)$ & $(2.16)$ & $(2.22)$ & $(0.44)$ & $(-0.27)$ & $(1.42)$ & $(1.29)$ \\
\hline \multirow[t]{2}{*}{$L C_{i t}$} & $0.001^{* *}$ & 0.000 & $0.001 * *$ & 0.001 ** & 0.005 & $0.014^{* * *}$ & -0.006 & -0.006 \\
\hline & $(2.55)$ & $(0.03)$ & $(2.07)$ & $(1.99)$ & $(0.67)$ & $(2.92)$ & $(-1.17)$ & $(-1.35)$ \\
\hline \multirow[t]{2}{*}{$S h 1_{i t}$} & 0.0019 & $0.002 * *$ & $-0.001 * *$ & $-0.001 *$ & 0.002 & 0.002 & 0.000 & 0.000 \\
\hline & (1.08) & (2.46) & $(-1.97)$ & $(-1.74)$ & $(0.93)$ & (0.83) & $(0.11)$ & $(0.22)$ \\
\hline \multirow[t]{2}{*}{$S O E_{i t}$} & 0.137 & 0.050 & 0.084 & 0.096 & -0.032 & -0.014 & -0.043 & -0.022 \\
\hline & (1.59) & $(0.63)$ & (1.39) & (1.54) & $(-0.72)$ & $(-0.24)$ & $(-1.15)$ & $(-0.76)$ \\
\hline \multirow[t]{2}{*}{$G D P_{i t}$} & $0.321^{* * *}$ & $0.225^{* * *}$ & $0.417^{* * *}$ & 0.134 ** & $0.444^{* * *}$ & $0.711^{* * *}$ & 0.166 ** & -0.094 \\
\hline & (3.63) & $(2.80)$ & $(9.71)$ & (2.41) & (4.44) & (5.91) & $(2.50)$ & $(-1.06)$ \\
\hline \multirow[t]{2}{*}{$F D I_{i t}$} & -4.183 & 0.707 & $-6.568^{* * *}$ & $-4.768^{* *}$ & 4.125 & 5.196 & -0.232 & 0.198 \\
\hline & $(-1.26)$ & $(0.18)$ & $(-3.14)$ & $(-2.30)$ & (1.08) & (1.21) & $(-0.10)$ & $(0.09)$ \\
\hline \multirow[t]{2}{*}{ Constant } & $17.340^{* * *}$ & $14.358^{* * *}$ & $3.492 * * *$ & $5.451^{* * *}$ & $16.119^{* * *}$ & $11.873^{* * *}$ & $5.340^{* * *}$ & $7.146^{* * *}$ \\
\hline & $(38.08)$ & $(34.71)$ & (9.78) & $(11.72)$ & (28.53) & (18.18) & $(6.02)$ & (7.77) \\
\hline Region & control & control & control & control & control & control & control & control \\
\hline $\operatorname{adj} . R^{2}$ & 0.194 & 0.095 & 0.722 & 0.727 & 0.125 & 0.188 & 0.663 & 0.674 \\
\hline $\mathrm{F}$ & 43.91 & 18.76 & 204.0 & 190.9 & 13.28 & 11.25 & 33.43 & 34.96 \\
\hline
\end{tabular}

Table 8 shows that the total factor productivity of both heavy polluting firms and non-heavy polluting firms will be affected by haze pollution. However, in terms of the total effect of haze pollution on the firms' TFP, non-heavy polluting firms are greatly affected by haze pollution, and the regression result coefficient of haze pollution on the firms' TFP is -0.572 , which is significant at the level of $1 \%$. For every $1 \%$ increase in haze pollution, the firms' TFP will decline by $0.572 \%$. The regression coefficient of haze pollution on labor productivity is -0.324 , which is significant at the level of $1 \%$. For every $1 \%$ increase in haze pollution, labor productivity will decline by $0.324 \%$. The coefficient of labor productivity on a firms' TFP is 0.8280 , which is significantly higher than $1 \%$, indicating that for every $1 \%$ increase in labor productivity, a firms' TFP will rise by $0.828 \%$. This indicates that in the test of an intermediary effect, haze pollution has a direct effect on a firms' TFP, and the direct effect is -0.304 .

Table 8 also shows that the total effect of haze pollution on a firms' TFP is -0.572 , the direct effect is -0.304 , and the indirect effect of haze pollution on a firms' TFP through reducing employees' labor productivity is $0.271(=-0.324 \times 0.835)$. Heavy polluting firms are less affected by haze pollution, and since the influence coefficient of haze pollution on a firms' TFP is not significant in the sixth column, it indicates that haze pollution does not affect the firms' TFP through affecting labor productivity.

The above analysis demonstrates that haze pollution has a great impact on the non-heavy-polluting firms' TFP and that it will affect total factor productivity by affecting labor productivity. Compared to non-heavy polluting firms, heavy polluting firms seem less affected by the total impact of haze pollution 
and do not have the intermediary of labor productivity. However, regarding the direct impact of haze pollution on a firms' TFP (column 8), heavy-polluting firms are more seriously affected.

\subsubsection{Ownership Difference}

In China, state-owned and non-state-owned enterprises face a very different policy environment. Promulgated by China's national economic research institute, China's province enterprise management environment index 2017 report also explicitly pointed out that the state-owned enterprises' operating environment was better than that of non-state-owned enterprises and that state-owned enterprises had a natural political advantage and higher employee benefits, which led workers to have a tendency to choose the state-owned enterprises (SOEs) as their first choice. In the face of haze pollution, state-owned enterprises may receive more policy support than non-state-owned enterprises, and due to welfare benefits and job stability, state-owned enterprise employees may be more tolerant of haze pollution than are non-state-owned enterprise employees. Therefore, to investigate the impact of haze pollution on the TFP of different types of enterprises, this paper divides the listed companies into state-owned enterprises and non-state-owned enterprises. The regression results are shown in Table 9.

Table 9. Heterogeneity Test 2-Ownership Heterogeneity.

\begin{tabular}{|c|c|c|c|c|c|c|c|c|}
\hline & (1) & (2) & (3) & (4) & (5) & (6) & (7) & (8) \\
\hline & \multicolumn{5}{|c|}{ Non-State-Owned } & \multicolumn{3}{|c|}{ State-Owned } \\
\hline Variable & $T F P_{-} L P_{i t}$ & Labor $_{i t}$ & $T F P_{-} L P_{i t}$ & $T F P_{-} L P_{i t}$ & $T F P_{-} L P_{i t}$ & Labor $_{i t}$ & $T F P_{-} L P_{i t}$ & $T F P_{-} L P_{i t}$ \\
\hline \multirow[t]{2}{*}{$P M_{2.5 i t-1}$} & $-\underset{* * *}{0.725}$ & $-\underset{* * *}{-0.382}$ & & $-\underset{* * *}{-0.400}$ & -0.128 & 0.097 & & $-0.201^{* * *}$ \\
\hline & $(-9.27)$ & $(-5.01)$ & & $(-8.46)$ & $(-1.41)$ & $(1.22)$ & & $(-3.02)$ \\
\hline \multirow[t]{2}{*}{ Labor $_{\text {it }}$} & & & $0.864^{* * *}$ & $0.853^{* * *}$ & & & $0.741^{* * *}$ & $0.743^{* * *}$ \\
\hline & & & $(31.03)$ & $(30.78)$ & & & $(13.42)$ & $(13.53)$ \\
\hline \multirow{2}{*}{$P r f_{i t}$} & -0.081 & 0.008 & $-0.095^{*}$ & -0.087 & -0.203 & -0.246 & -0.033 & -0.021 \\
\hline & $(-1.34)$ & $(0.19)$ & $(-1.70)$ & $(-1.57)$ & $(-0.54)$ & $(-1.27)$ & $(-0.10)$ & $(-0.06)$ \\
\hline \multirow{2}{*}{$L e v_{i t}$} & $0.355^{* * *}$ & 0.025 & $0.356^{* * *}$ & $0.334^{* * *}$ & -0.355 & $-0.857^{* *}$ & $0.276^{*}$ & $0.281 *$ \\
\hline & $(2.79)$ & $(0.23)$ & $(5.20)$ & $(4.91)$ & $(-1.22)$ & $(-2.53)$ & $(1.79)$ & $(1.84)$ \\
\hline \multirow[t]{2}{*}{ Grow $_{\text {it }}$} & 0.010 & 0.020 & -0.007 & -0.007 & 0.018 & $0.028 * *$ & -0.003 & -0.003 \\
\hline & $(0.70)$ & $(1.56)$ & $(-1.23)$ & $(-1.29)$ & $(1.34)$ & $(2.42)$ & $(-0.39)$ & $(-0.36)$ \\
\hline \multirow[t]{2}{*}{$B t m_{i t}$} & $0.247^{* * *}$ & $0.163^{* * *}$ & $0.105^{* * *}$ & $0.108^{* * *}$ & $0.122 * *$ & $0.101^{* *}$ & 0.049 & 0.047 \\
\hline & $(4.24)$ & $(4.44)$ & $(2.98)$ & (3.13) & (2.05) & $(2.43)$ & (1.51) & (1.49) \\
\hline \multirow[t]{2}{*}{$L C_{i t}$} & 0.000 & -0.002 & $0.002^{* * *}$ & $0.002^{* * *}$ & $0.001^{* * *}$ & 0.001 & 0.000 & 0.000 \\
\hline & $(0.45)$ & $(-1.41)$ & $(5.87)$ & (5.58) & $(5.80)$ & $(1.58)$ & $(0.95)$ & $(0.88)$ \\
\hline \multirow[t]{2}{*}{$S h 1_{i t}$} & 0.001 & $0.003^{* *}$ & -0.001 & -0.001 & -0.001 & -0.006 & -0.001 & -0.001 \\
\hline & $(1.31)$ & $(2.47)$ & $(-1.43)$ & $(-1.36)$ & $(-0.97)$ & $(-0.35)$ & $(-1.09)$ & $(-0.88)$ \\
\hline \multirow[t]{2}{*}{$G D P_{i t}$} & $0.340 * * *$ & $0.336^{* * *}$ & $0.416^{* * *}$ & 0.053 & $0.354^{* * *}$ & $0.485^{* * *}$ & $0.173^{* * *}$ & -0.006 \\
\hline & (3.75) & $(3.77)$ & $(8.85)$ & $(0.91)$ & (3.29) & $(4.75)$ & $(2.69)$ & $(-0.07)$ \\
\hline \multirow[t]{2}{*}{$F D I_{i t}$} & $-9.921 *$ & -1.666 & $\underset{* * *}{-10.099}$ & $\underset{* * *}{-8.501}$ & -4.591 & -1.672 & $-4.751 *$ & -3.349 \\
\hline & $(-1.85)$ & $(-0.36)$ & $(-3.01)$ & $(-2.58)$ & $(-1.22)$ & $(-0.38)$ & $(-1.85)$ & $(-1.39)$ \\
\hline \multirow[t]{2}{*}{ Constant } & $17.738^{* * *}$ & $14.265^{* * *}$ & $2.987^{* * *}$ & $5.570 * * *$ & $16.460^{* * *}$ & $12.890^{* * *}$ & $5.699 * * *$ & $6.887^{* * *}$ \\
\hline & $(36.97)$ & $(30.14)$ & $(8.81)$ & $(12.28)$ & $(27.64)$ & $(25.17)$ & $(7.67)$ & $(8.15)$ \\
\hline Region & control & control & control & control & control & control & control & control \\
\hline adj. $R^{2}$ & 0.230 & 0.120 & 0.741 & 0.749 & 0.114 & 0.120 & 0.636 & 0.639 \\
\hline F & 52.72 & 22.40 & 224.2 & 208.6 & 13.58 & 8.010 & 34.57 & 34.14 \\
\hline
\end{tabular}

Note: ${ }^{* * *}, * *$ and $*$ represent statistically significant at the $1 \%, 5 \%$, and $10 \%$ levels, respectively; brackets are $t$ values. 
Table 9 reveals that the TFP of both state-owned and non-state-owned enterprises will be affected by haze pollution. For non-state-owned listed companies, the total effect of haze pollution on their TFP is -0.725 , which is significant at the level of $1 \%$. The regression coefficient of haze pollution on labor productivity is -0.382 , which is significant at the level of $1 \%$. In the third and fourth column of Table 9, the regression coefficients of labor productivity and haze pollution on TFP are 0.864 and -0.370 , respectively, which are significant at the level of $1 \%$. The direct effect of haze pollution on the TFP of non-state-owned enterprises is -0.370 , and the channel effect of reducing TFP by reducing labor productivity is $-0.330(=-0.382 \times 0.864)$; that is, the indirect effect is -0.330 . For state-owned enterprises, the regression coefficient of haze pollution in columns 5 and 6 in Table 9 is not significant, indicating that haze pollution does not reduce the TFP of state-owned enterprises by affecting their labor productivity. As seen from the regression coefficients of haze pollution in columns 1 and 8 in the table, the TFP of non-state-owned enterprises is more affected by haze pollution than is that of state-owned enterprises.

\subsection{Endogeneity Problem}

\subsubsection{Regression of an Instrumental Variable}

Since the production and the operation of firms will cause damage to the air environment, there may be an endogenous problem between haze pollution and a firm's TFP. This paper chooses to use instrumental variables to solve the endogeneity problem. The influence of instrumental variables on explained variables can only be realized by affecting endogenous variables. The difficulty of using the instrumental variable method lies in the determination of appropriate instrumental variables that not only generally meet a number of statistical indicators but also have a convincing logical derivation [63]. The condition that an instrumental variable in this paper needs to satisfy is that it is sufficiently related to haze pollution and will not directly or indirectly affect a firm's TFP through other factors other than haze pollution. According to the above requirements, we find that the total number of local environmental laws and regulations in force in the place where the enterprise is located can serve as a good instrumental variable for haze pollution. First, haze pollution is sufficiently related to the total number of effective local environmental laws and regulations. When the local environment pollution is more serious, the local government will use more effective local environmental laws and regulations to control the local environmental quality and changes. Second, the total number of effective local environmental laws and regulations is not related to a firm's TFP. Environmental regulations are not participating inputs in the business activities of the enterprise; therefore, they will not affect a firm's TFP. Therefore, this paper takes the total number of local environmental laws and regulations in effect in the province where the enterprise is located based on the China Statistical Yearbook on Environment as an instrumental variable and further estimates the impact of haze pollution on a firm's TFP within the unified framework of the two-stage least squares (2SLS) method. The 2SLS method was proposed by Theil [64] in 1953. It is not only suitable for structural equations that are exactly identified, but also suitable for structural equations that are over-identified. The 2SLS estimation method is divided into two stages: the first stage is to find suitable instrumental variables; the second stage is to estimate the structural parameters with the least squares estimation of the model. The regression results are shown in Table 10.

On the whole, the regression results of the first stage show that the number of environmental regulations in the province where the enterprise is located is significant at the level of $1 \%$ and that the $F$ test value in the first stage is much higher than the empirical value of 10 , thus significantly excluding the problem of a "weak instrumental variable." In the second stage, the influence of haze pollution on a firm's TFP is significantly negative, which further verifies that haze pollution can indeed reduce a firm's TFP. 
Table 10. Endogenous Resolution— two-stage least squares (2SLS).

\begin{tabular}{|c|c|c|}
\hline \multirow{2}{*}{ Variable } & First-Stage & Second-Stage \\
\hline & $P M_{2.5 i t-1}$ & $T F P_{-} L P_{i t}$ \\
\hline \multirow{2}{*}{$\operatorname{Law}_{i t}$} & $0.017^{* * *}$ & \\
\hline & (5.39) & \\
\hline \multirow{2}{*}{$P M_{2.5 i t}$} & & $-1.830^{* *}$ \\
\hline & & $(-2.54)$ \\
\hline \multirow{2}{*}{$\operatorname{Prf} f_{i t}$} & 0.018 & -0.054 \\
\hline & (1.52) & $(-0.78)$ \\
\hline \multirow{2}{*}{$\operatorname{Lev}_{i t}$} & $-0.038^{*}$ & 0.165 \\
\hline & $(-2.59)$ & (1.16) \\
\hline \multirow{2}{*}{ Grow $_{i t}$} & -0.000 & 0.014 \\
\hline & $(-0.19)$ & (1.51) \\
\hline \multirow{2}{*}{$\mathrm{Btm}_{i t}$} & -0.002 & $0.145^{* * *}$ \\
\hline & $(-0.43)$ & (3.70) \\
\hline \multirow{2}{*}{$L C_{i t}$} & -0.000 & $0.001^{* * *}$ \\
\hline & $(-0.89)$ & $(2.81)$ \\
\hline \multirow{2}{*}{$S h 1_{i t}$} & $0.000 * *$ & $0.002 *$ \\
\hline & $(2.01)$ & (1.68) \\
\hline \multirow{2}{*}{$S O E_{i t}$} & $0.040^{* *}$ & $0.159 *$ \\
\hline & (2.22) & $(2.22)$ \\
\hline \multirow{2}{*}{$G D P_{i t}$} & $-0.907^{* * *}$ & -0.813 \\
\hline & $(-58.44)$ & $(-1.23)$ \\
\hline \multirow{2}{*}{$F D I_{i t}$} & $5.456^{* * *}$ & 0.333 \\
\hline & (5.84) & $(0.07)$ \\
\hline Industry & control & control \\
\hline Region & control & control \\
\hline$R^{2}$ & 0.644 & 0.074 \\
\hline$F$ & 29.08 & 53.93 \\
\hline
\end{tabular}

Note: ${ }^{* * *}, * *$ and * represent statistically significant at the $1 \%, 5 \%$, and $10 \%$ levels, respectively; brackets are $t$ values.

\subsubsection{Haze Pollution and Labor Productivity Lag by One Period Respectively}

To further solve the endogeneity problem, the mediating variables and the explanatory variables in the model must lag one year behind the original data. Since the haze pollution in the initial regression model lags by one year, it is necessary to lag the haze pollution by two years and labor productivity by one year to perform the model regression again. The regression results are shown in Table 11.

Table 11. Endogenous Resolution-Lag Variables.

\begin{tabular}{|c|c|c|c|c|}
\hline \multirow{2}{*}{ Variable } & M1 & M2 & M3 & M4 \\
\hline & $T F P_{-} L P_{i t}$ & Labor $_{i t-1}$ & $T F P_{-} L P_{i t}$ & $T F P_{-} L P_{i t}$ \\
\hline \multirow{2}{*}{$P M_{2.5 i t-2}$} & $-0.676^{* * *}$ & $-0.163^{* *}$ & & $-0.653^{* * *}$ \\
\hline & $(-9.47)$ & $(-2.17)$ & & $(-9.45)$ \\
\hline \multirow{2}{*}{ Labor $_{i t}-1$} & & & $0.151^{* * *}$ & $0.143^{* * *}$ \\
\hline & & & $(4.00)$ & $(3.84)$ \\
\hline \multirow{2}{*}{$\operatorname{Prf} f_{i t}$} & $-0.502^{* *}$ & -0.068 & $-0.542^{* *}$ & $-0.492^{* *}$ \\
\hline & $(-2.00)$ & $(-0.47)$ & $(-2.19)$ & $(-1.97)$ \\
\hline \multirow{2}{*}{$L e v_{i t}$} & $0.220 *$ & -0.044 & $0.227 *$ & $0.226 *$ \\
\hline & $(1.67)$ & $(-0.45)$ & $(1.74)$ & $(1.73)$ \\
\hline \multirow{2}{*}{ Grow $_{i t}$} & 0.003 & -0.017 & 0.003 & 0.005 \\
\hline & $(0.27)$ & $(-1.40)$ & $(0.27)$ & $(0.50)$ \\
\hline
\end{tabular}


Table 11. Cont.

\begin{tabular}{|c|c|c|c|c|}
\hline \multirow{2}{*}{ Variable } & M1 & M2 & M3 & M4 \\
\hline & $T F P_{-} L P_{i t}$ & Labor $_{i t-1}$ & $T F P_{-} L P_{i t}$ & $T F P_{-} L P_{i t}$ \\
\hline \multirow{2}{*}{$\mathrm{Btm}_{i t}$} & $0.102 * *$ & $0.119 * * *$ & $0.124^{* * *}$ & $0.085 *$ \\
\hline & (2.31) & (2.74) & $(2.91)$ & (1.95) \\
\hline \multirow{2}{*}{$L C_{i t}$} & $0.002^{* * *}$ & $-0.001^{* * *}$ & $0.002 * * *$ & $0.002 * * *$ \\
\hline & $(3.00)$ & $(-3.79)$ & (3.13) & (3.19) \\
\hline \multirow{2}{*}{$\operatorname{Sh} 1_{i t}$} & $0.002 *$ & 0.000 & 0.001 & $0.002 *$ \\
\hline & $(1.70)$ & $(0.39)$ & $(1.31)$ & (1.66) \\
\hline \multirow{2}{*}{$S O E_{i t}$} & 0.081 & 0.011 & 0.064 & 0.079 \\
\hline & $(1.08)$ & $(0.17)$ & $(0.88)$ & (1.16) \\
\hline \multirow{2}{*}{$G D P_{i t}$} & $0.157^{* *}$ & 0.066 & $0.597^{* * *}$ & $0.148^{* *}$ \\
\hline & $(2.12)$ & $(0.82)$ & $(8.65)$ & $(2.01)$ \\
\hline \multirow{2}{*}{$F D I_{i t}$} & $5.089 *$ & 5.113 & 1.589 & 4.361 \\
\hline & $(1.80)$ & $(1.11)$ & $(0.56)$ & $(1.57)$ \\
\hline \multirow{2}{*}{ Constant } & $18.362^{* * *}$ & $14.215^{* * *}$ & $12.488^{* * *}$ & $16.337^{* * *}$ \\
\hline & $(44.02)$ & $(33.45)$ & $(25.01)$ & $(27.32)$ \\
\hline Industry & control & control & control & control \\
\hline Region & control & control & control & control \\
\hline adj. $R^{2}$ & 0.182 & 0.047 & 0.168 & 0.200 \\
\hline F & 46.64 & 10.97 & 36.42 & 47.95 \\
\hline
\end{tabular}

Note: ${ }^{* * * * *} \overline{\text { and }^{*} \text { represent statistically significant at the } 1 \%, 5 \% \text {, and } 10 \% \text { levels, respectively; brackets }}$ are $t$ values.

Table 11 shows that the coefficient of haze pollution in $\mathrm{M} 1$ is -0.6763 , which is significant at the level of $1 \%$, indicating that haze pollution will significantly reduce a firm's TFP. The test results verify Hypothesis 1. In Table 11, the influence coefficient of M2 haze pollution on the labor productivity of firms is -0.163 , which is significant at the level of $5 \%$. For every $1 \%$ increase in haze pollution, labor productivity will decline by $0.163 \%$, indicating that the increase in haze pollution will reduce the labor productivity of employees. In M3, the coefficient of labor productivity on a firm's TFP is 0.151 , which is significant at the level of $1 \%$, indicating that for every $1 \%$ increase in labor productivity, a firm's TFP will rise by $0.151 \%$. In M4, it can be seen that the coefficient of haze pollution on a firm's TFP is -0.653 , which is significant at the level of $1 \%$. This also indicates that in the mediation effect test, haze pollution has a direct effect on firm's TFP, and the direct effect is $\delta_{1}=-0.653$. The analysis of the intermediary effect shows that in M1-M4, the total effect of haze pollution on firm's TFP is $\alpha_{1}=-0.676$, the direct effect is $\delta_{1}=-0.653$, and the indirect effect of haze pollution on a firm's TFP through reducing employees' labor productivity is -0.023 ; that is, the mediation effect is -0.023 .

\section{Conclusions and Policy Implications}

Based on the data of A-share listed companies from 2013 to 2017 and the air quality monitoring data released by the China National Environmental Monitoring Centre, this paper conducts an empirical test on the relationship between haze pollution, labor productivity and firm-level TFP by using the mediation effect test model. The results show the following: first, haze pollution will reduce a firm's TFP; second, labor productivity plays a partial intermediary role between haze pollution and firm-level TFP: haze pollution will not only have a direct negative impact on a firm-level TFP but also reduce a firm-level TFP by reducing enterprise labor productivity. Subsequently, the robustness test was carried out by means of the substitution of independent variables and dependent variables, and the results all supported the hypotheses in this paper. In addition, this paper also carries out a heterogeneity analysis of the industry and the ownership of the listed companies and finds that heavy polluting and non-state-owned enterprises are more susceptible to haze pollution. In addition, in non-heavy polluting enterprises and non-state-owned enterprises, haze pollution will also reduce the firm-level 
TFP by reducing labor productivity, while in heavy polluting enterprises and state-owned enterprises, labor productivity does not play the role of an intermediary.

This study reveals the importance of preventing and controlling haze pollution from a micro perspective and provides empirical evidence for local governments to formulate and effectively implement environmental policies and for firms to improve their competitiveness. First, improving TFP is an important way to achieve economic development. In addition to considering the economic strength of enterprises and regions, external factors should also be taken into consideration. Local governments often fail to protect the environment when making economic policies or even sacrifice the environment for economic growth due to officials' own political promotion considerations. Therefore, in formulating environmental policies, governments need to recognize that economic growth and environmental protection are not incompatible and that poor air quality not only endangers health, but also causes problems such as declining productivity. At the same time, local economic growth should and the environment should be included in the evaluation. In addition, when formulating policies, governments should take into account the characteristics of enterprises and their industries and should implement targeted policies. Second, a good working environment is also an important noncommodity welfare item for employees. To prevent labor loss, firms should take the negative effect caused by air pollution on labor force into consideration when formulating management policies and designing a salary system. Firms should also invest more in green innovation, create cleaner working conditions for their workforce, and attract and retain talents.

Author Contributions: Data curation, S.S.; Funding acquisition, B.L. and Y.Z.; Resources, B.L.; Supervision, B.L. and Y.Z.; Writing—original draft, S.S. and Y.Z.; Writing-review \& editing, B.L. and Y.Z. All authors have read and agreed to the published version of the manuscript.

Funding: National Natural Science Foundation of China: No. 71603306; Science Foundation of Ministry of Education of China: No. 20YJC790005; Fundamental Research Funds for the Central Universities: No. BUCTRC201808; Funds for First-class Discipline Construction of Beijing University of Chemical Technology: No. XK1802-5.

Acknowledgments: This work was supported by MOE (Ministry of Education in China) Project of Humanities and Social Sciences (Grant No. 20YJC790005), the Fundamental Research Funds for the Central Universities (Grant No. BUCTRC201808), the Fundamental Research Funds for the Central Universities (Grant No. PT2016) and Funds for First-class Discipline Construction of Beijing University of Chemical Technology (Grant No. XK1802-5).

Conflicts of Interest: The authors declare no conflict of interest.

\section{References}

1. Xi, J.P. Secure a Decisive Victory in Building a Moderately Prosperous Society in all Respects and Strive for the Great Success of Socialism with Chinese Characteristics for a New Era. Qiushi 2018, 1, 3-65.

2. Schiffbauer, M.; Siedschlag, I.; Ruane, F. Do Foreign Mergers and Acquisitions Boost Firm Productivity? Int. Bus. Rev. 2017, 26, 1124-1140. [CrossRef]

3. Duguet, E. Innovation Height, Spillovers and TFP Growth at the Firm Level: Evidence from French Manufacturing. Econ. Innov. New Technol. 2006, 15, 415-442. [CrossRef]

4. Wu, Y.; Song, Y.; Deng, G. Institutional Environment, OFDI, and TFP Growth: Evidence from China. Emerg. Mark. Financ. Trade 2017, 53, 2020-2038. [CrossRef]

5. Kose, M.A.; Prasad, E.S.; Terrones, M.E. Does Openness to International Financial Flows Raise Productivity Growth? J. Int. Money Financ. 2009, 28, 554-580. [CrossRef]

6. Cole, M.A. Air Pollution and 'Dirty' Industries: How and Why Does the Composition of Manufacturing Output Change with Economic Development? Environ. Resour. Econ. 2000, 17, 109-123. [CrossRef]

7. Heck, T.; Hirschberg, S. China: Economic Impacts of Air Pollution in the Country. In Encyclopedia of Environmental Health; Elsevier: Amsterdam, The Netherlands, 2011; pp. 625-640.

8. Hanlon, W.W.; UCLA. Coal Smoke and the Costs of the Industrial Revolution. In NBER Working Papers; National Bureau of Economic Research: Cambridge, MA, USA, 2016.

9. Kebin, H.; Hong, H.; Qiang, Z. Urban Air Pollution in China: Current Status, Characteristics, and Progress. Annu. Rev. Energy Environ. 2011, 27, 397-431. 
10. Chen, R.; Kan, H.; Chen, B.; Huang, W.; Bai, Z.; Song, G.; Pan, G. Association of Particulate Air Pollution with Daily Mortality: The China Air Pollution and Health Effects Study. Am. J. Epidemiol. 2012, 175, 1173-1181. [CrossRef]

11. Chan, C.K.; Yao, X. Air Pollution in Megacities in China. Atmos. Environ. 2008, 42, 1-42. [CrossRef]

12. Ma, J.; Xu, X.; Zhao, C.; Yan, P. A Review of Atmospheric Chemistry Research in China: Photochemical Haze, Haze Pollution, and Gas-Aerosol Interactions. Adv. Atmos. Sci. 2012, 29, 1006-1026. [CrossRef]

13. Tao, M.; Chen, L.; Xiong, X.; Zhang, M.; Ma, P.; Tao, J.; Wang, Z. Formation Process of the Widespread Extreme Haze Pollution over Northern China in January 2013: Implications for Regional Air Quality and Climate. Atmos. Environ. 2014, 98, 417-425. [CrossRef]

14. Wang, C.; Cai, J.; Chen, R.; Shi, J.; Yang, C.; Li, H.; Lin, Z.; Meng, X.; Liu, C.; Niu, Y. Personal Exposure to Fine Particulate Matter, Lung Function and Serum Club Cell Secretory Protein (Clara). Environ. Pollut. 2017, 225, 450-455. [CrossRef] [PubMed]

15. Bulletin of China's Ecological Environment. Available online: http://www.cnemc.cn/jcbg/zghjzkgb/201905/ P020190529486578089674.pdf (accessed on 5 June 2018). (In Chinese)

16. Matus, K.; Nam, K.M.; Selin, N.E.; Lamsal, L.N.; Reilly, J.M.; Paltsev, S. Health Damages from Air Pollution in China. Glob. Environ. Chang. 2012, 22, 55-66. [CrossRef]

17. Wan, Y.; Yang, H.; Masui, T. Air Pollution-Induced Health Impacts on The National Economy of China: Demonstration of A Computable General Equilibrium Approach. Rev. Environ. Health 2005, 20, 119-140.

18. Li, T.; Liu, H.; Salvo, A. Severe Air Pollution and Labor Productivity. In IZA Discussion Papers; IZA Institute of Labor Economics: Bonn, Germany, 2015.

19. Fu, S.; Viard, V.B.; Zhang, P. Air Quality and Manufacturing Firm Productivity: Comprehensive Evidence from China. In MPRA Paper; Munich Personal RePEc Archive: Munich, Germany, 2017.

20. He, J.; Haoming, L.; Alberto, S. Severe Air Pollution and Labor Productivity: Evidence from Industrial Towns in China. Am. Econ. J. Appl. Econ. 2019, 11, 173-201. [CrossRef]

21. Chang, T.Y.; Graff Zivin, J.; Gross, T.; Neidell, M. The Effect of Pollution on Worker Productivity: Evidence from Call Center Workers in China. Am. Econ. J. Appl. Econ. 2019, 11, 151-172. [CrossRef]

22. Li, B.; Guo, P.; Zeng, Y. The Impact of Haze on the Availability of Company Debt Financing: Evidence for Sustainability of Chinese Listed Companies. Sustainability 2019, 11, 806. [CrossRef]

23. Solow, R.M. Technical Change and the Aggregate Production Function. Rev. Econ. Stat. 1957, 39, 312-320. [CrossRef]

24. Iii, P.; Arden, C. Lung Cancer, Cardiopulmonary Mortality, and Long-term Exposure to Fine Particulate Air Pollution. JAMA 2002, 287, 1132-1141.

25. Lelieveld, J.; Evans, J.S.; Fnais, M.; Giannadaki, D.; Pozzer, A. The Contribution of Outdoor Air Pollution Sources to Premature Mortality on A Global Scale. Nature 2015, 525, 367-371. [CrossRef]

26. Franchini, M.; Mannucci, P.M. Air Pollution and Cardiovascular Disease. Thromb. Res. 2012, 129, $230-234$. [CrossRef] [PubMed]

27. Adetutu, M.; Glass, A.J.; Kenjegalieva, K.; Sickles, R.C. The Effects of Efficiency and TFP Growth on Pollution in Europe: A Multistage Spatial Analysis. J. Prod. Anal. 2015, 43, 307-326. [CrossRef]

28. Zhao, X.; Gao, Z. Spatial Externalities, Environmental Pollution and Total Factor Productivity Growth in China Evidence from a Spatial Panel Data Set of Provincial-Level; IEEE: Piscataway, NJ, USA, 2011; pp. 440-444.

29. Chen, S.; Chen, D. Haze Pollution, Government Governance and High-quality Economic Development. Econ. Res. J. 2018, 53, 20-34.

30. Miller, S.M.; Upadhyay, M.P. The Effects of Openness, Trade Orientation, and Human Capital on TFP. J. Dev. Econ. 2000, 63, 399-423. [CrossRef]

31. Gang, Y.; Fan, G.A. A Theoretical Analysis on Economic Growth in China and Total Factor Productivity. Econ. Res. J. 2003, 8, 13-20.

32. Key, N.; Mcbride, W.D.; Mosheim, R. Decomposition of TFP Change in the U.S. Hog Industry. J. Agric. Appl. Econ. 2008, 40, 137-149. [CrossRef]

33. Beveren, I.V. Total Fator Productivity Estimation: A Practical Review. J. Econ. Surv. 2012, 26, 98-128. [CrossRef]

34. Duguet, E. Knowledge Diffusion, Technological Innovation and TFP Growth at the Firm Level: Evidence from French Manufacturing. In Papiers Deconomie Mathã@matique Et Applications; University of Paris I: Paris, France, 2001. 
35. Majumdar, R. Firm Specific Management Decisions on TFP Growth in Indian Electronics Industry during Liberalisation. Int. J. Econ. Policy Emer. Econ. 2010, 3, 272-294.

36. Coates, J.M.; Herbert, J. Endogenous Steroids and Financial Risk Taking on A London Trading Floor. Proc. Natl. Acad. Sci. USA 2008, 105, 6167-6172. [CrossRef]

37. Chew, S.H.; Huang, W.; Li, X. Does Haze Cloud Decision Making? A Natural Laboratory Experiment; Beihang University: Beijing, China, 2018.

38. Shao, Y.H.; Xiao-Ning, B.U.; Zhang, T.H. Resource Misallocations and TFP of Chinese Industrial Enterprises-A Recalculation Based on Chinese Industrial Enterprises Database. China Ind. Econ. 2013, 12, 39-51.

39. Calligaris, S. Misallocation and TFP in Italy: Evidence from Firm-Level Data. Labour 2015, 29, $367-393$. [CrossRef]

40. Hsieh, C.T.; Klenow, P.J. Misallocation and Manufacturing TFP in China and India. Q. J. Econ. 2009, 124, 1403-1448. [CrossRef]

41. Hopenhayn, H.A. Firms, Misallocation, and Aggregate Productivity: A Review. Annu. Rev. Econ. 2014, 6, 735-770. [CrossRef]

42. Gollop, F.M.; Roberts, M.J. Environmental Regulations and Productivity Growth: The Case of Fossil-Fueled Electric Power Generation. J. Political Econ. 1983, 91, 654-674. [CrossRef]

43. Gray, W.B. The Cost of Regulation: OSHA, EPA and the Productivity Slowdown. Am. Econ. Rev. 1987, 77, 998-1006.

44. Chay, K.Y.; Greenstone, M. Air Quality, Infant Mortality, and the Clean Air Act of 1970; National Bureau of Economic Research: Cambridge, MA, USA, 2003.

45. Enrico, M.; Matthew, N. Pollution, Health, and Avoidance Behavior: Evidence from the Ports of Los Angeles. J. Hum. Resour. 2011, 46, 154-175.

46. Pope, C.A., III; Burnett, R.T.; Turner, M.C.; Cohen, A.; Krewski, D.; Jerrett, M.; Gapstur, S.M.; Thun, M.J. Lung Cancer and Cardiovascular Disease Mortality Associated with Ambient Air Pollution and Cigarette Smoke: Shape of the Exposure-Response Relationships. Environ. Health Perspect. 2011, 119, 1616-1621. [CrossRef]

47. Zivin, J.G.; Neidell, M. The Impact of Pollution on Worker Productivity. Am. Econ. Rev. 2012, 102, 3652-3673. [CrossRef]

48. Chang, T.; Graff Zivin, J.; Gross, T.; Neidell, M. Particulate Pollution and the Productivity of Pear Packers. Am. Econ. J. Econ. Policy 2016, 8, 141-169. [CrossRef]

49. Qin, Y.; Zhu, H. Run away? Air pollution and Emigration Interests in China. J. Popul. Econ. 2018, 31, $235-266$. [CrossRef]

50. Van Tilburg, W.A.P.; Sedikides, C.; Wildschut, T. Adverse Weather Evokes Nostalgia. Personal. Soc. Psychol. Bull. 2018, 44, 984-995. [CrossRef] [PubMed]

51. Sass, V.; Kravitz-Wirtz, N.; Karceski, S.M.; Hajat, A.; Crowder, K.; Takeuchi, D. The Effects of Air Pollution on Individual Psychological Distress. Health Place 2017, 48, 72-79. [CrossRef] [PubMed]

52. Lu, J.G.; Lee, J.J.; Gino, F.; Galinsky, A.D. Polluted Morality: Air Pollution Predicts Criminal Activity and Unethical Behavior. Psychol. Sci. 2018, 29, 340-355. [CrossRef] [PubMed]

53. Higdon, R.; Van Belle, G.; Kolker, E. The Effect of Pollution on Labor Supply: Evidence from a Natural Experiment in Mexico City. J. Public Econ. 2015, 122, 68-79.

54. Li, Z.; Folmer, H.; Xue, J. To What Extent Does Air Pollution Affect Happiness? The Case of the Jinchuan Mining Area, China. Ecol. Econ. 2014, 9, 88-99. [CrossRef]

55. Spector, P.E.; Fox, S. An Emotion-Centered Model of Voluntary Work Behavior: Some Parallels between Counterproductive Work Behavior and Organizational Citizenship Behavior. Hum. Resour. Manag. Rev. 2003, 12, 269-292. [CrossRef]

56. Beck, A.; Crain, A.L.; Solberg, L.I.; Unützer, J.; Glasgow, R.E.; Maciosek, M.V.; Whitebird, R. Severity of Depression and Magnitude of Productivity Loss. Ann. Fam. Med. 2016, 9, 305-311. [CrossRef]

57. Baron, R.M.; Kenny, D.A. The Moderator-Mediator Variable Distinction in Social Psychological Research: Conceptual, Strategic, and Statistical Considerations. J. Personal. Soc. Psychol. 1986, 51, 1173. [CrossRef]

58. Olley, G.S.; Pakes, A. The Dynamics of Productivity in the Telecommunications Equipment Industry. Econometrica 1996, 64, 1263-1297. [CrossRef]

59. Levinsohn, J.; Petrin, A. Estimating Production Functions Using Inputs to Control for Unobservables. Rev. Econ. Stud. 2010, 70, 317-341. [CrossRef] 
60. Lu, X.D. Estimation of TFP of Industrial Enterprises in China: 1999-2007. China Econ. Q. 2012, 11, 541-558.

61. Yang, C.H.; Lin, C.H.; Ma, D. R\&D, Human Capital Investment and Productivity: Firm-level Evidence from China's Electronics Industry. China World Econ. 2010, 18, 72-89.

62. İmrohoroğlu, A.; Tüzel, Ş. Firm-level productivity, risk, and return. Manag. Sci. 2014, 60, $2073-2090$. [CrossRef]

63. Acemoglu, D.; Johnson, S.; Robinson, J.A. The colonial origins of comparative development: An empirical investigation. Am. Econ. Rev. 2001, 5, 1369-1401. [CrossRef]

64. Theil, H. Repeated least squares applied to complete equation systems. In The Hague: Central Planning Bureau; Mineo: The Hague, The Netherlands, 1953.

Publisher's Note: MDPI stays neutral with regard to jurisdictional claims in published maps and institutional affiliations.

(C) 2020 by the authors. Licensee MDPI, Basel, Switzerland. This article is an open access article distributed under the terms and conditions of the Creative Commons Attribution (CC BY) license (http://creativecommons.org/licenses/by/4.0/). 